トピックス

\section{粘塑性圧力媒体を用いた 静水圧押出法の開発}

\section{山口喜 弘*}

\section{1. はじめに}

超高流体圧を利用した押出加工法, 静水生押出法の原 理は古くは1893 年の Robertson の英国特許(1) そ見るこ とができる、いっぽう, 実験的研究は 1950 年頃になさ れた Bridgman の試み(2)を最初とする. Robertson の特 許では高圧流体による潤滑作用が強調されている。 また Bridgman の試みは, 金属材料の破壊延性が静水圧下で 著しく増大するとともに高静水圧下で予ひずみを与える とそうでない場合に比し残留延性が大きくなるといら彼 の実験的知見を動機としていた。これらの事実は静水圧 押出法のその後の展開を顧みるときに重要である。

Bridgman の実験的試み以来, 各国で $1 / 4$ 世紀にわたっ て活発清静水压押出法に関する研究開発がなされてき た ${ }^{(3)}$ が, 新しい塑性加工法として工業的に利用されるよ うになったのは極めて最近のことである. 静水圧押出法 の工業化までの歩みが遅かったのは，10２0 kbar とい らような超高圧を日常的に使いこなす超高圧装置技術の 開発に時間を要したこと, 当初難加工材料への適用に関 心がかたよったためにすぐれた基本的特長を有しなが ら, 生産性が高く利用しやすいプロセスに発展させる努 カがじゅうぶんなされなかったことなどによるものと考 えられる. 本稿では静水圧押出法の基本的な特長と問題 点を述べるとともに筆者らが開発した粘塑性圧力媒体を 用いた静水王押出法を紹介する.

\section{2. 静水圧押出法の基本的特長と問題点}

静水圧押出法はビレットの周囲に高圧の圧力媒体が介 在することによる次のような特長を有している.

（1）ビレットと圧力容器内壁とは直接接触せず，その 間の摩擦は存在しない. 中空ビレットを押出す際にはビ レット内壁とマンドレル側壁間の摩擦も同様に存在しな い.したがって長尺ビレットを有効に押出すことができ る.また同一容器でそれが収用しうる範用では種々の形

* 株式会社神戸製鋼所中央研究所主任研究員 A New Simplified Hydrostatic Extrusion Process; Yoshihiro Yamaguchi (Central Research Laboratory. Kobe Steel, Ltd, Kobe)

1975 年 4 月 3 日受理
状寸法のビレットを押出加工できる。 そのため従来の押 出法にはない融通性が生じる.

（2）ダイス変形領域に入る以前のビレットには基本的 には静水圧応力が作用するだけであり，従来の押出法で 生じるビレットの予めのすえこみ变形は生じない，その ために管押出し時の偏肉抑制, 複合ビレット押出し時の 健全性の維持が容易になる。

（3）高圧流体による強制潤滑作用によってビレットと 工具との摩擦損失が他のいかなる押出加工法よりも小さ くでき加工荷重が低減できる. この特長は高押出速度で も維持される．また，そのために円錐状ダイスのような 余剩せん断ひずみを小さくできるダイスを有効に利用で きるので効果は一層大きくなる，潤滑状態が良好なので 工具と焼付き易い材料の押出加工や薄肉異形材の精密加 工が容易になる。

(4) ビレットと工具との摩擦が小さいことと円錐状あ るいはそれに類似したダイスを用いらることにより，加 工変形領域の大部分に高静水圧応力が作用するととも に，横断面にわたって塑性変形が均一になる．このこと は低延性材料の押出加工を可能とし，また押出材の性質 を一般に良好なものにする. 背圧下へ押出す場合にはこ の特長がより顕著になることがある.

（5）圧力媒体の存在によって容器内壁はもちろんダイ スやマンドレルの摩耗が少なくなる。またダイスの外周 に高静水圧を作用させることができるので薄肉ダイスを 利用できる、マンドレルもビレットとの摩擦に起因する 引張応力を低減できるので従来の管押出法に比し強度上 の制約を大幅に軽減できる.

いっぽう，静水圧押出法は高圧の圧力媒体を利用する ことにともなら次のような問題点を内在する.

（1）圧力媒体は圧縮性を有し，またビレットと工具間 の潤滑状態は押出速度に依存することから, 押出しに際 してスティック・スリップのような動的不安定現象を生 じることがある。

（2）従来の押出法に捣けるようなビレットの擦過によ る容器内壁の摩耗等の損傷はないが, 容器内面の初期欠 陥や疲労き裂への圧力媒体の浸入による押し挔げ作用に より, 容器の設計条件が厳しくなる.

（3）圧力媒体の容器への注入, 排出が必要であり, 押 出装置が複雑になり, サイクルタイムが長くなりがちで ある。

（4）高温で静水圧押出しするに際して，加熱ビレット を容器に插入後圧力媒体を注入すると, 圧力媒体の乱流 などによってビレット温度が低下しやすい。 


\section{3. 静水圧押出法の工業的利用と粘塑性圧力 媒体を用いた静水圧押出法の開発}

静水圧押出法工業化の過程は前述の基本的な特長を活 かしたままで，その問題点をいかに解消するかにあった といらことができる.

第 1 の問題点, 静水圧押出し時の動的不安定現象の直 接的な抑制法としては，押出しに際して静水圧の他に製 品に前方張力, あるいはビレット後端に軸圧縮力を同時 に付加する方法が提案されている(3)(4). これらの方法は 非常に有効であるが, 装置上あるいは操業上に複雑さ をもたらすことは否定できない。ハイドラフィルム (Hydrafilm) 法 ${ }^{(5)}$ はこの点に関して興味深い方法であ る. この方法では容器とビレットの間吵を $0.3 \mathrm{~mm}$ 程度 と小さくし，かつ圧力媒体の量を少なくして，押出開始 時にビレットの予めのすえこみ変形が過大にならない範 囲でステム先端とビレット後端の直接接触を許容する. この方法はプロセスの簡易化と動的不安定現象の抑制に 効果的であるが，静水圧押出法が本来有する融通性を犠 牲にしているとも考えられる。ビレットあるいは容器内 にダンパを取付け安定化する方法も提案されたが，工業 的見地からは一般的ではない，ところで静水圧押出し時 の動的不安定現象は意外に容易なそして好ましい別の方 法で解消しうることが明らかになった。 それは押出速度 を高くすることである(6). 工業的に利用される範囲の押 出速度, たとえば $10 \mathrm{~mm} / \mathrm{sec}$ 程度のビレット速度では 押出初期から潤滑状態が良好になり, 安定な押出しが実 現される。このようにして現時点ではこの問題点は実質 上解決されたといらことができる.

第 2 の問題点, 容器の強度については, 円筒内壁に予 め高い圧縮残留応力を与えることによって圧力媒体のき 裂への浸入効果を抑制しらることが見出され，15 kbar 程度の圧力に対しては経済的に許容できる寿命を有する 容器の設計が可能になってきている(7).

第 3 ，第 4 の問題点は圧力媒体を用いることにともな ら不可避的な要素として装置技術上の工夫でそれらの欠 点を補ら努力がなされてきた。

このような過程において，1970年前後から冷間での 静水圧押出法の工業的利用が各国でなされ始めた。用途 は変形能や押出材の材質に対する制限から高温加工が好 ましくない合金や複合材，精度や表面性状の観点で冷間 加工が必要な製品の押出加工であり，圧力媒体としては 大気圧下で適度な粘度を有し，圧力にともなら粘度上昇 が鉱物油のようには著しくなく，かつある程度の耐熱性 を有するひまし油のよらな液体が用いられている。

しかし，変形抵抗や破壊延性の観点から高温で加工す ることが望ましい金属材料に静水圧押出法を適用するこ とを考えるとき，圧力媒体として液体を用いる従来の方
法では前述の第 3 ，第 4 の問題点が厳しい制約になる. 筆者らはこのような背景の下で粘塑性圧力媒体を用いた 静水圧押出法を開発した ${ }^{(8)}$.

この方法の概略を図 1 に示す.図1 (a)はビレットの 容器内への插入に先だって塊状の圧力媒体が容器後端部 に㨀入された状態を示す．塊状の圧力媒体は予め加熱さ れていてもよい.つぎに図 1 (b)に示すように容器内に ビレットが挿入される。まずビレット後端が圧力媒体に 接し,さらに容器とビレットの相対移動が進さにした がってビレットと容器の間隙に圧力媒体が流入し, 空気 を排除する，そしてダイスと容器間でシールがなされる と直ちにステムが前進し,静水圧が発生し，押出しがなさ れる，その状態を図1 (c)に示している. 押出し終了後 圧力媒体はステムにより容器外に排出, 回収され, 再使 用される。この方法によれば静水圧押出法の基本的特長 をいささかもそこならことなく常温ならびに高温のビ レットを簡易に押出加工することができる，装置も従来 の押出プレスに近い構造に単純化される．圧力媒体の注 入，排出に要する時間も液体を用いる場合に比し短縮で きる，予め加熱されたビレットを粘塑性圧力媒体を用い て静水圧押出しする場合にはビレットの容器内滞留時間 が短くかつ圧力媒体が乱流を生じにくいので温度低下が 小さい。このことは同時に容器等への熱影響が小さいこ とを意味する。

(a)

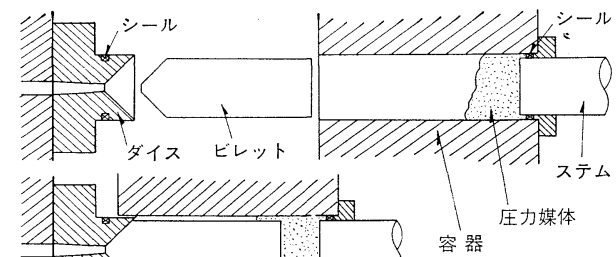

(c)

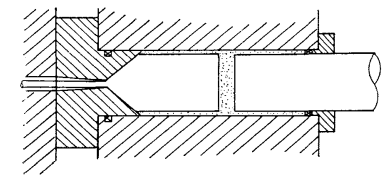

図 1 粘塑性圧力媒体を用いた静水圧押出法.

この方法で用いられる圧力媒体は所定温度で容器内に 挿入される際に作用する重力等の外力で流動しないだけ のせん断降伏応力を有し，かつ押出圧力下で注ぼ静水圧 的に圧力を伝達しらる特性を有する非ニュートン流体で ある必要がある。使用温度等によって選択されるが，特 定のグリース，ワックスと油脂の混合物等がこの特性を 満たす圧力媒体として利用される。

この方法で各種材料を高温で静水王押出しした結果の 例を図 2 に示す．モリブデンは冷間では延性が低いので 加工困難であるが，高温では健全に押出加工できる．銅 
合金やアルミニウム合金は温度上昇とともに変形抵抗が 著しく低下するので, 高温域では非常に高い押出比で加 工できる。また，従来の直接あるいは間接押出法では表 面割れのため数 $\mathrm{m} / \mathrm{min}$ 程度の低速でしか押出加工でき ない2024のようなアルミニウム合金が高温静水圧押出 法では $200 \mathrm{~m} / \mathrm{min}$ 以上の高速で健 全に押出されること が明らかになっている。

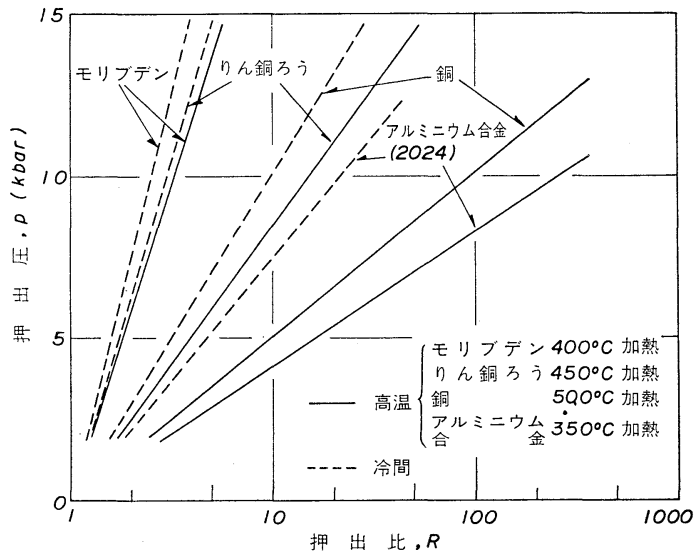

図 2 冷間および高温静水圧押出しにお活る押出圧。

\section{4. を と め}

静水圧押出しは各国の中で特に我国において工業化が 積極的に進められている。そして新しい技術の常として 特殊な用途からより一般的な用途に利用分野が拡りつつ ある．そのような動向の 1 つとして粘塑性圧力媒体を用 いた簡易化された静水压押出法を紹介した。

\section{文献}

(1) J.Robertson : British Patent No.19356 (1893).

(2) P.W.Bridgman : Studies in Large Plastic Flow and Fracture, McGraw Hill, (1952).

(3) 例えば H.L1.D.Pugh : The Mechanical Behaviour of Materials under Pressure, Elsevier Pub.Co. Ltd., (1970).

(4) H. K. Slater and D. Green : High Pressure Engineering, IME, (1967), 109.

(5) R.J.Fiorentino, G.E.Meyer and T.G.Byrer : SME Paper, MF 71-103(1971).

（6）たとえば西原正夫, 藤田 達, 山口喜弘, 松下 富春, 野口昌孝: 塑性と加工, $13(1972), 178$.

(7) 西原正夫, 山口喜弘, 服部重夫 : 塑性と加工, 15 (1974), 696 .

（8）藤田達, 山口喜弘, 松下富春, 野口昌孝, 山崎 龍雄 : R \& D/神戸製鋼技報, $24(1974) ， 46$.

\section{一分科会報告}

宿題テーマ研究会

\section{高融点金属材料の基礎的諸問題}

上記研究会が，第I · III総合分科，東北支部，文部省 科研費総合研究班の共催で， 6 月 11，12，13 日と川渡 共同セミナーセンターで開かれた．参加者は北は札幌か ら南は福岡まで全国から64名に達した。講演は総合研 究班のメンバーによるものが大部分であった。プログラ ムを次に示そう。

[6月 11 日]

(1) モリブデソ中の炭素の拡散

東北大工 平野賢一 飯島嘉明

(2) バナジゥムの酸素スネークピークに及ぼす合金元 素の効果 東大工 四䆠樹男 石野 湫 三島良績

(3) 電子線照射損傷と侵入型原子の相互作用 北大工 竹山太郎 高橋平七郎

(4) $B C C$ 金属の高温変形に及ぼす侵入型不純物原子 の影響

[6 月 12 日]

(5) $\mathrm{V}_{\mathrm{a}}$ 族金属による水素のピックアップ

東北大金研 阿部勝憲 吉永日出男 諸住正太郎

（6）急冷法による $V_{\mathbf{a}}$ 族金属中の水素, 重水素の研究

（7） Ta 中の水素によるスネーク効果 東北大金研 花田黎門 東大工 岩瀬彰宏 阪本甲子郎
（8）ニッケルおよび鉄中の水素の回復過程

阪大基磷工 山川浩二 藤田英一

（9）パルス NMR による金属中の水素拡散の研究 中大理工 深井 有 風間重雄 杉本秀彦

(10) $\mathrm{Nb}-\mathrm{H}$ 系の NMR 金材研 中村恵吉

（11）バナジウムの水素脆性と動的観察 東大物性研 鈴木 平 小池茂年

(12） BCC 金属における $\{110\}$ 異常すべり

（13）高温変形における内部応力 東北大金研 松井秀樹 木村 宏 東北大金研 阿部勝憲 吉永日出男 諸住正太郎

(14） $B C C$ 金属の靶性と転位のセル構造との関係 東理大工 橋口隆吉

（15）18-8 ステンレス鋼に打けるマルテンサイト変態 と結晶塑性

東大物生研 鈴木 平 橋本辰男 小島日出夫

（16）鉄単結晶の機械的性質に及ぼす低温中性子照射 効果

[6月 13 日] 九大応力研 北島一德 安倍博信 原研 高村三郎 奥田重雄

(17) バナジウムの Radiation Anneal Hardening に ついて 東大工 脇田淳一 四謇樹男 中村仁一 石野 刑 三島良績

（18）中性子照射したバナジウムの焼鈍硬化 原研 白石健介 深谷 清 片野吉男

（19）Mo およびWの電子照射と格子欠陥 阪大基碟工 桐谷道雄 高田広志 前原泰裕

（20） $B C C$ 金属の格子間原子 原研 奥田重雄 水林 博 